\title{
PENDAMPINGAN PEMBUATAN MIKRO ORGANISME LOKAL (MOL) BAGI MASYARAKAT DESA SALU INDUK
}

\author{
Nurmalasari ${ }^{*}$ \\ Suhaeni ${ }^{2}$ \\ 1 Program Studi Kimia Universitas Cokroaminoto Palopo, Palopo, Indonesia \\ 2 Program Agroteknologi, Universitas Cokroaminoto Palopo, Palopo, Indonesia \\ nur87.mipa@gmail.com ${ }^{1 *}$ \\ suhaenicimba01@gmail.com $^{2)}$
}

Kata Kunci: [Bioaktivator, Mikroorganisme local]
Abstrak: Desa Saluinduk merupakan salah satu desa dengan komoditi utama tanaman padi. Kegiatan pengabdian kepada masyarakat ini dilakukan di Desa Saluinduk, Kabupaten Luwu, Provinsi Sulawesi Selatan. Sasaran dalam kegiatan ini adalah kelompok tani Saluinduk. Tujuan kegiatan pengabdian kepada masyarakat ini adalah memberikan pengetahuan kepada petani padi tentang cara memperoleh mikroorganisme lokal (MOL). Metode yang diterapkan dalam kegiatan ini berupa workshop dan pendampingan praktik pembuatan MOL. Hasil pendampingan menunjukkan bahwa petani memahami pengetahuan tentang pupuk organik cair berbahan MOL dan cara pembuatannya.

\section{Pendahuluan}

Desa Salu Induk merupakan salah satu desa yang terletak di Kecamatan Bua Ponrang Kabupaten Luwu. Masyarakat di desa ini mayoritas adalah petani. Hal ini didukung oleh kondisi lingkungan pegunungan sehingga memungkinkan masyarakatnya melaksanakan kegiatan petanian. Dalam pertanian umumnya menggunakan pupuk sebagai sumber nutrisi. Kebutuhan pupuk kuhusunya pupuk kimia digunakan untuk menyuburkan tanah. Pupuk kimia mudah diserap oleh tanah karena ukuran molekulnya yang kecil. Namun penggunaan pupuk kimia dalam jangka waktu yang lama, memungkinkan zat-zat kimia akan terakumulasi dalam tanaman yang bisa menyebabkan penyakit jika dikonsumsi oleh manusia. Selain pupuk kimia terkadang masyarakat didesa tersebut juga menggunakan pupuk kompos. Pupuk kompos yang digunakan diperoleh dari salah satu produsen pupuk dan berbayar. Padahal bahan utama dalam pembuatan pupuk kompos tersedia dilingkungan mereka sendiri.

Pembuatan pupuk kompos memerlukan bantuan mikroba. Sumber mikroba dapat diperoleh dari EM4. Mikroba dapat juga diperoleh dengan membuat larutan bioaktivator mikroorganisme local (MOL). Bioaktivator ini menggunakan bahan-bahan sisa seperti seperti nasi, buah, bonggol pisang, keong mas, urin (Budiyani et al., 2016; Suhastyo et al., 2013). Bahan-bahan tersebut harus difermentasi hingga menjadi MOL. Aplikasi MOL pada proses pengomposan mampu menghasilkan pupuk kompos yang sesuai dengan standar (Hadiwidodo et al., 2018; Kalay et al., 2020; Lepongbulan et al., 2017; Zahanis et al., 2018). 
Kurangnya pengetahuan masyarakat Salu Induk akan hal ini menyebabkan biaya yang digunakan dalam pertanian juga tinggi. Sehubungan dengan hal tersebut, kegiatan ini perlu dilaksanakan. Kegiatan ini merupakan bentuk pengabdian kepada masyarakat sebagai implementasi dari Tri Dharma Perguruan Tinggi. Kegiatan ini bertujuan untuk memberikan pengetahuan tentang cara pembuatan pupuk MOL dan memberikan informasi kepada masyarakat tentang penggunaan bahan alami dilingkungan sekitar sebagai biokativator.

\section{Metode Pelaksanaan}

Kegiatan ini dilaksanakan pada bulan mei-juni 2019 di desa Salu Induk. Petani yang terlibat pada kegiatan ini sebanyak 26 orang yang terdiri dari petani padi dan coklat. Kegiatan diawali dengan identifikasi masalah melalui kegiatan observasi di lokasi. Khalayak sasaran ditentukan berdasarkan tingkat pengetahuan masyarakat mengenai MOL dan yang memiliki hambatan pada perolehan pupuk kimia.

Pemberian materi dilaksanakan di balai desa Salu Induk. Pelaksanaan kegiatan diawali dengan pemaparan tujuan dan manfaat yang akan diperoleh dalam kegiatan. Kegiatan ini dihadiri oleh pemerintah desa beserta peserta yang merupakan petani di desa Salu Induk. Kegiatan workshop dilaksanakan dengan memberikan materi berupa, teori manfaat serta pengaruh MOL terhadap tanaman. Setelah pemaparan materi dilanjutkan sesi diskusi.

Pelatihan pembuatan MOL melibatkan peserta. Bahan yang digunakan adalah nasi yang telah berjamur sebanyak 500 gram dimasukkan ke dalam wadah bertutup (toples). Selanjutnya ditambahkan gula merah 500 gram kg, air kelapa 1 liter, Setelah semua tercampur toples ditutup dan bagian tengah tutup toples tersebut di lubangi dengan diamater $1 \mathrm{~cm}$ lalu dihubungkan dengan selang plastik bening ke dalam botol aqua yang berisi air 1,5 L. Larutan MOL yang telah dibuat di toples selanjutnya difermentasikan di sekitar akar tanaman bambu hingga 14 hari, dan MOL siap diaplikasikan.

\section{Hasil dan Pembahasan}

Setelah mendapatkan materi mengenai MOL, peserta yang hadir memahami keterlibatan mikroorganisme yang terlibat dalam penyerapan nutrisi pada tanaman. Selain itu mereka lebih memahami perbedaan MOL dengan pupuk kompos dan kandang. Ada tujuh pertanyaan terkait bahan yang digunakan metode fermentasi yang dilakukan. Pertanyaan menarik lainnya dilontarkan oleh salah satu peserta terkait pupuk kandang. Pentingnya pengetahuan dalam menggunakan pupuk sangatlah perlu, sehingga perlu adanya edukasi terkait nutrisi yang terkandung dalam setiap pupuk. Kegiatan pemaparan materi ditutup dengan foto bersama, sebagai mana pada Gambar 1.

Pada proses pembuatan MOL, masyarakat bersama dengan panitia terlibat dalam penyiapan bahan hingga proses fermentasi. MOL yang dihasilkan sebanyak 2 toples atau setara dengan 3 Liter. Pada proses fermentasi yang dilakukan di akar tanaman bambu, muncul pertanyaan dari peserta mengenai keunggulan fermentasi di akar bambu. Hasil fermentasi menunjukkan bahwa warna MOL berubah menjadi coklat pekat dengan aroma yang menyengat menyerupai bau tape. 


\section{Pembahasan}

Pelaksanaan kegiatan diawali dengan pembekalan terhadap masyarakat terkait mikroorganisme seperti yang ditampilkan pada GAmbar 1. Tujuan dari pembekalan ini adalah menambah pengetahuan petani terkait mikrorganisme yang terlibat dalam penyerapan unsur hara. Mikroorganisme yang dimanfaatkan pada kegiatan ini adalah Plant Growth Promoting Rhizobacteria (PGPR) berupa Pseudomonas sp, Chaetomium globosum, Aspergillus sp., Paecilomyces sp., dan Mortierella sp. (Asniah et al., 2013). Mikroba ini dapat berperan dalam meningkatkan pertumbuhan tanaman. Mikroba ini juga dapat berperan sebagai biofertilizer yang mampu mempercepat proses pertumbuhan melalui percepatan penyerpan unsur hara. Pertumbuhan tanaman terjadi karena PGPR berperan sebagai stimulan yang dapat menghasilkan fitohormon pertumbuhan (Yulistiana et al., 2020).

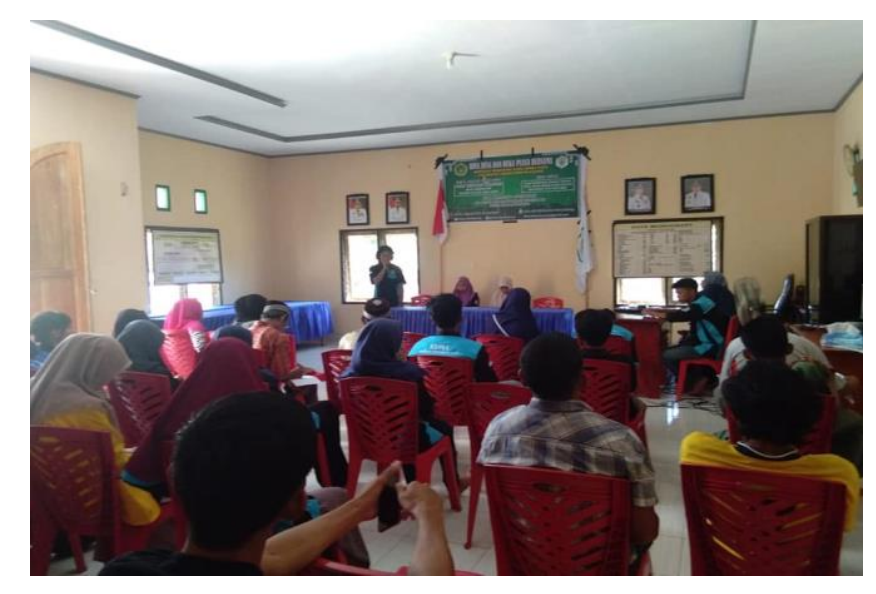

Gambar 1. Pemaparan materi

Pada tahapan fermentasi seperti pada Gambar 2, ada pertanyaan dari peserta bahwa, alasan apa yang mendasari proses fermentasi harus dilakukan di sekitar perakaran bambu. Pertanyaan tersebut ditanggapi dengan memberikan gambaran mengenai ketahanan bambu terhadap cuaca ekstrim, penebangan, pembakaran serta kesuburan bambu. Bambu dapat bertahan bahkan tumbuh subur tanpa dipupuk. Pada perakaran bambu terdapat PGPR atau bakteri yang terdapat pada rizhosfer yaitu daerah perakaran. Mikroorganisme rhizoper atau Rhizobakteri dapat menyelubungi permukaan akar sehinggga akar dapat menyerap nutrisi.

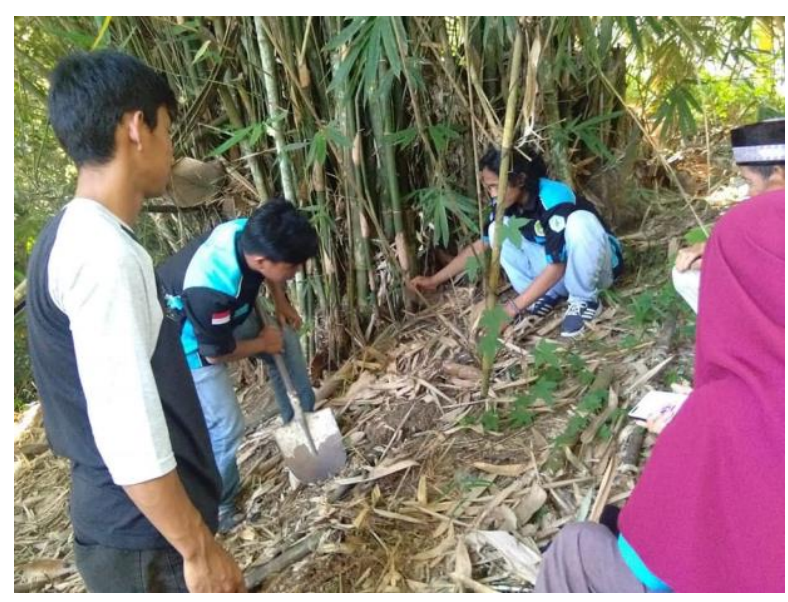

Gambar 2. Proses penggalian tempat fermentasi pada perakaran bambu 
MOL merupakan produk konsentrat, dapat diaplikasikan dengan takaran 1/5 larutan. MOL dapat diaplikasikan sebagai dekomposer maupun sebagai pemacu pertumbuhan tanaman. Sebagai decomposer MOL dapat dengan mudah diaplikasikan pada pembuatan kompos.

\section{Kesimpulan}

Masyarakat Salu Induk lebih memahami mengenai MOL dan cara pembuatannya serta cara mengaplikasikan MOL.

\section{Ucapan Terimakasih}

Terima kasih kepada pemerintah Desa Salu Induk dan seluruh masyarakat yang terlibat pada kegiatan ini.

\section{Referensi}

Asniah, A., Widodo, W., \& Wiyono, S. (2013). Potensi Cendawan Asal Tanah Perakaran Bambu Sebagai Endofit dan Agen Biokontrol Penyakit Akar Gada Pada Tanaman Brokoli. 13(1), 61-68.

Budiyani, N. K., Soniari, N. N., \& Sutari, N. W. S. (2016). Analisis Kualitas Larutan Mikroorganisme Lokal (MOL) Bonggol Pisang. Jurnal Agroekoteknologi Tropika (Journal of Tropical Agroecotechnology).

Hadiwidodo, M., Sutrisno, E., Handayani, D. S., \& Febriani, M. P. (2018). Studi Pembuatan Kompos Padat Dari Sampah Daun Kering Tpst Undip Dengan Variasi Bahan Mikroorganisme Lokal (MOL) Daun. Jurnal Presipitasi: Media Komunikasi Dan Pengembangan Teknik Lingkungan, 15(2), 78-85. https://doi.org/10.14710/presipitasi.v15i2.78-85

Kalay, A. M., Sesa, A., Siregar, A., \& Talahaturuson, A. (2020). Efek Aplikasi Pupuk Hayati terhadap Populasi Mikroba dan Ketersediaan Unsur Hara Makro pada Tanah Entisol. Agrologia, 8(2), Article 2. https://doi.org/10.30598/a.v8i2.1011

Lepongbulan, W., Tiwow, V. M. A., \& Diah, A. W. M. (2017). Analisis Unsur Hara Pupuk Organik Cair dari Limbah Ikan Mujair (Oreochromis mosambicus) Danau Lindu dengan Variasi Volume Mikroorganisme Lokal (MOL) Bonggol Pisang. Jurnal Akademika Kimia, 6(2), 92. https://doi.org/10.22487/j24775185.2017.v6.i2.9239

Suhastyo, A. A., Anas, I., Santosa, D. A., \& Lestari, Y. (2013). STUDI MIKROBIOLOGI DAN SIFAT KIMIA MIKROORGANISME LOKAL (MOL) YANG DIGUNAKAN PADA BUDIDAYA PADI METODE SRI (System of Rice Intensification). Sainteks, 10(2), Article 2. https://doi.org/10.30595/sainteks.v10i2.148

Yulistiana, E., Widowati, H., \& Sutanto, A. (2020). PLANT GROWTH PROMOTING RHIZOBACTERIA (PGPR)DARI AKAR BAMBU APUS (Gigantochola apus) MENINGKATKAN PERTUMBUHAN TANAMAN. 1(1), 1-7.

Zahanis, Z., Widodo Haryoko, W. H., \& Megi Martavia, M. M. (2018). Pengaruh Pemberian Bahan Organik yang Diperkaya Mikroba Bambu Terhadap Pertumbuhan dan Produksi Kangkung Darat (Ipomoea reptans). JUrnal EMBRIO, 10(1), 57-72. 